\title{
CrimRxiv
}

\section{The Digital Rights}

\section{Movement: The Role of}

\section{Technology in Subverting Digital Copyright}

Hector Postigo

Published on: Oct 01, 2012

DOI: $10.21428 / \mathrm{cb} 6 \mathrm{ab} 371.440510 f 9$

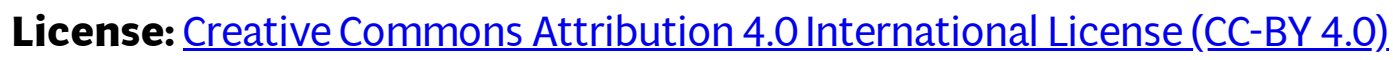


